\title{
PENGARUH PROTEIN CSN1S2 DARI SUSU DAN YOGURT KAMBING PERANAKAN ETHAWAH TERHADAP KOMPOSISI MIKROBIOTA PADA FESES TIKUS RA-CFA
}

\section{EFFECT OF CSN1S2 PROTEIN ETHAWAH CROSSBREED MILK AND YOGURT ON THE COMPOSITION OF MICROBIOTA IN RA-CFA FECAL RATS}

\author{
Adhya Dava Aligarh Yahya ${ }^{1}$, Eko Suyanto ${ }^{1,2)}$, Fatchiyah Fatchiyah ${ }^{1,2) *}$
}

Diterima : 9 Juni 2020

Disetujui : 19 Agustus 2020

\section{Afiliasi Penulis: \\ 1) Program Studi Biologi, Fakultas \\ Matematika dan Ilmu Pengetahuan \\ Alam, Universitas Brawijaya, Indonesia \\ 2) Research Center of Smart \\ Molecule of Natural Genetics \\ Resources (SMONAGENES), \\ Universitas Brawijaya, Indonesia}

\section{Alamat Korespondensi:}

*fatchiya@ub.ac.id

\section{Cara Sitasi:}

Yahya, A.D.A, E. Suyanto, \& F. Fatchiyah. 2020. Pengaruh protein CSN1S2 dari susu dan yogurt kambing peranakan ethawah terhadap komposisi mikrobiota pada feses tikus RA-CFA: Journal of Tropical Biology 8 (2): 106-115.

ABSTRAK
Rheumatoid arthritis (RA) merupakan salah satu penyakit autoimun yang
menyebabkan inflamasi pada jaringan sinovial. Prevalensi RA semakin meningkat
setiap tahunnya dan berpotensi menghambatproduktivitas. Komposisi mikrobiota
merupakan salah satu faktor lingkungan yang mempengaruhi perkembangan
penyakit RA. Tujuan penelitian ini adalah untuk mengamati efek pemberian
protein CSNIS2 susu dan yogurt peranakan Ethawah terhadap komposisi
mikrobiota pada usus tikus rheumatoid arthritis yang diinduksi Complete
Freund's Adjuvant (CFA). Tikus dibagi menjadi dua model yakni kontrol dan RA
yang masing - masing diberi perlakukan protein CSN1S2 susu dan yogurt. Feses
yang diperoleh lalu dianalisis total koloni bakteri, isolasi bakteri, karakterisasi,
perhitungan indeks Simpson, isolasi DNA bakteri dan amplifikasi gen 16S sRNA.
Hasil menunjukkan bahwa pemberian protein CSN1S2 pada model hewan
mempengaruhi komposisi bakteri dengan peningkatan jumlah koloni bakteri pada
kelompok RAM dan RAY. Pada perlakuan kontrol dan RA didominasi oleh
kelompok bakteri Lactobacillus berdasarkan analisis gen 16S rRNA. Kelompok
Lactobacillus lebih banyak ditemukan pada perlakuan kontrol dibandingkan RA.
Lactobacillus berperan dalam mempengaruhi perkembangan penyakit RA, serta
mampu menghambat bakteri patogen dari golongan Clostridium dan
Enterococcus, ini bergantung pada tingkat spesies bakteri tersebut.
Kata kunci: disbiosis, mikrobiota usus, rheumatoid arthritis, susu, yogurt

\section{ABSTRACT}

Rheumatoid arthritis (RA) is an autoimmune disease that causes inflammation of the synovial tissue. The prevalence of $R A$ is increasing every year and has the potential to hamper productivity. Microbiota composition is an environmental factor that influences the development of RA. The aim of this study was to observe the effect of CSN1S2 protein from ethawah crossbreed milk and yogurt on the composition of microbiota in rheumatoid arthritis rats induced by Complete Freund's Adjuvant (CFA). Rats were divided into two models namely control and $R A$, each of which had three groups. The feces obtained were analyzed by calculating total bacterial colonies, isolation, characterization, Simpson index, DNA isolation and $16 S$ SRNA gene amplification. The results showed that giving CSN1S2 protein from milk and yogurt of Ethawah crossbreed goat in animal models affected the bacterial composition by increasing the number of colonies in the RAM and RAY groups. The analysis of the results of the 16S rRNA gene amplification of bacteria showed that the control and RA treatments were a group of Lactobacillus bacteria. The Lactobacillus group was more prevalent in the control treatment than $R A$. Lactobacillus plays a role in influencing the development of $R A$ disease, and is able to inhibit the pathogenic bacteria of the Clostridium and Enterococcus groups; this depends on the level of the bacterial species.

Keywords: dysbiosis, intestinal microbiota, rheumatoid arthritis, milk, yogurt 


\section{PENDAHULUAN}

Rheumatoid arthritis (RA) adalah penyakit sistemik, inflamasi, dan kronis yang ditandai dengan respons imun persisten yang mengarah pada peradangan dan kerusakan sendi [1]. Hal ini menyebabkan penderita akan mengalami kecacatan fungsional pada sinovium, tulang rawan dan tulang sejati [2]. Berdasarkan hasil riset kesehatan dasar tahun 2018 melaporkan bahwa prevalensi penderita RA mencapai $11,9 \%$ dari total populasi penduduk di Indonesia. Angka prevalensi diperkirakan semakin meningkat setiap tahun sehingga berpotensi menghambat produktivitas serta berdampak pada kematian [3]. Studi epidemiologis menunjukkan bahwa RA sebagai hasil dari interaksi kompleks antara gen, faktor lingkungan, hormon, dan sistem kekebalan tubuh [1]. Faktor lingkungan seperti mikrobiota usus memainkan peran penting dalam perkembangan penyakit radang sendi [4]. Perubahan komposisi mikrobiota pada usus (disbiosis) dapat menyebabkan perubahan lapisan sel epitel usus sehingga meningkatkan paparan oleh berbagai bakteri [5].

Penelitian sebelumnya tentang karakterisasi dan pemahaman mengenai mikrobiota usus telah berkembang, terutama terkait penyakit autoimun. Mikrobiota usus adalah sumber utama mikroba yang dapat memberikan efek bermanfaat serta patogen pada kesehatan manusia [6]. Mikrobiota yang seimbang menjaga respons imun melalui interaksi dengan sel epitel usus, yang membantu mempertahankan keadaan toleran dalam saluran pencernaan [7]. Bakteri komensal berperan penting dalam menekan respon inflamasi dan mempromosikan toleransi imunologis. Mikrobiota dapat mengatur diferensiasi subset limfosit, selain itu mikrobiota spesifik dapat mempengaruhi fungsi kekebalan tubuh [8]. Penelitian di Amerika sebelumnya melaporkan bahwa penderita RA yang tidak diobati memiliki peningkatan jumlah bakteri Prevotella copri yang lebih banyak dan berkurangnya kelimpahan spesies bakteri Bacteroides di usus [9]. Sebuah penelitian di Cina juga melaporkan bahwa pasien RA mengalami peningkatan jumlah Lactobacillus salivarius dalam usus [10]. Komposisi mikrobiota sebagian besar ditentukan oleh kebutuhan nutrisi tubuh dan sangat bervariasi di berbagai lokasi saluran usus yang dapat berfungsi menjadi pelindung terhadap kolonisasi bakteri patogen penyebab RA [11].
Susu kambing menawarkan banyak manfaat kesehatan karena rendah lemak dan laktosa serta kaya dengan kalsium, antioksidan, sifat antimikroba dan komponen fungsional lainnya [12]. Lactococcus dan Lactobacillus yang diisolasi dari susu kambing segar dan susu fermentasi di Selangor dan Jeniang, Malaysia mampu menghambat pertumbuhan bakteri patogen pada saluran pencernaan seperti, Bacillus cereus, B. subtilis, Enterococcus faecalis, E. faecium, Listeria monocytogene, E. coli O157:H7, E. coli V517, Salmonella typhi, Pseudomonas aeruginosa, dan Enterobacter aerogenes [13]. Susu kambing merupakan sumber utama peptida bioaktif yang berfungsi sebagai immunomodulator dan agen anti inflamasi [14]. Penelitian sebelumnya melaporkan bahwa pada susu kambing peranakan ethawah ditemukan peptida bioaktif yaitu protein CSN1S2 dengan berat molekul 36 $\mathrm{kDa}$ yang memiliki fungsi salah satunya sebagai antimikroba [15].

Penelitian mengenai pengaruh pemberian protein CSN1S2 dari susu dan yogurt kambing peranakan ethawah terhadap komposisi mikrobiota dalam feses tikus model RA - CFA, serta mekanisme penghambatan mikrobiota usus yang mempengatuhi penyakit RA masih belum jelas. Pemberian protein CSN1S2 dari susu dan yogurt kambing peranakan ethawah diharapkan mampu menghambat pertumbuhan bakteri patogen pada model hewan RA. Tujuan penelitian ini adalah untuk mendapatkan informasi tentang pengaruh pemberian protein CSN1S2 dari susu dan yogurt kambing peranakan Ethawah terhadap komposisi mikrobiota dalam feses hewan model (Rattus norvegivus) RA yang diinduksi dengan Complete Freund's Adjuvant. Penelitian yang dilakukan hanya untuk mengetahui komposisi bakteri pada tingkat genus atau dalam penelitian ini tidak dilakukan teknik sekuensing.

\section{METODE PENELITIAN}

Kode etik. Studi ini telah dievaluasi dan disetujui oleh Universitas Brawijaya, Malang, Jawa Timur, Indonesia (nomer registrasi, KEP90-UB).

Isolasi protein dan perlakuan hewan. Isolasi protein CSN1S2 (berat molekul $36 \mathrm{kDa}$ ) pada susu dan yogurt dilakukan menggunakan SDS-PAGE menurut penelitian sebelumnya [16-17]. Tikus Wistar umur 12 minggu dengan berat 150-200 gr diinjeksi dengan Complete Freund's Adjuvant (CFA) sesuai prosedur sebelumnya hingga menjadi tikus rheumatoid 
arthritis (RA) [17]. Pembuatan tikus model RA dilakukan menurut penelitian sebelumnya menggunakan metode induksi CFA sebanyak $100 \mu \mathrm{L}$ secara subkutan (SIGMA,USA) dan 14 hari kemudian diinjeksi kembali dengan CFA sebanyak $50 \mu \mathrm{L}$ secara intradermal [18].

Pengambilan sampel. Sampel feses didapatkan dari berbagai macam perlakuan pada tikus Wistar jantan (Rattus norvegicus) yang terbagi menjadi 2 kelompok yaitu tikus kontrol dan tikus RA. Pada tikus kontrol terdiri dari 3 perlakuan yaitu kontrol (tanpa perlakuan) (C), perlakuan kontrol penambahan protein CSN1S2 susu (CM) dan perlakuan kontrol penambahan protein CSN1S2 yogurt (CY) sedangkan pada tikus RA terdiri dari 3 perlakuan yaitu tikus penyakit RA (RA), perlakuan RA penambahan protein CSN1S2 susu (RAM) dan perlakuan RA penambahan protein CSN1S2 yogurt (RAY), masing-masing perlakuan memiliki 3 ulangan. Sampel feses dari tiap perlakuan dimasukkan ke dalam microtube $1,5 \mathrm{~mL}$ steril kemudian disimpan dalam kulkas pada suhu $-80^{\circ} \mathrm{C}[19]$.

Total koloni bakteri. Perhitungan jumlah total bakteri dilakukan menggunakan metode total plate count (TPC) pada media Plate Count Agar (PCA). Sampel feses sebanyak $1 \mathrm{~g}$ disuspensikan dalam $9 \mathrm{~mL}$ garam fisiologis $(\mathrm{NaCl} 0,9 \%)$ dalam masing - masing tabung reaksi kemudian dilakukan serial dilusi. Sampel hasil dilusi diambil sebanyak $0,1 \mathrm{~mL}$ lalu diinokulasi menggunakan teknik pour plate pada cawan petri yang berisi medium PCA. Sampel diinkubasi pada suhu $37^{\circ} \mathrm{C}$ selama 48 jam. Koloni bakteri yang tumbuh dihitung menggunakan colony counter dan dikonversi melalui perhitungan hingga diperoleh total koloni bakteri.

Indeks keragaman. Keragaman bakteri pada feses tikus dari tiap perlakuan dapat diketahui dengan perhitungan menggunakan indeks keragaman Simpson. Jumlah koloni bakteri yang memiliki morfologi berbeda dihitung. Data yang didapatkan kemudian dihitung menggunakan rumus Id [20].

$$
\mathrm{D}=1-\left\{\sum \mathrm{n}(\mathrm{n}-1) / \mathrm{N}(\mathrm{N}-1)\right\}
$$

Keterangan:

$\mathrm{D}=$ indeks diversitas

$\mathrm{n}=$ jumlah individu

$\mathrm{N}=$ jumlah total individu yang ditemukan

Nilai indeks keragaman Simpson berkisar antara $0-1$ dengan representasi sebagai berikut:
0-0,30 Dominansi rendah, keragaman tinggi. 0,31-0,6 Dominansi sedang, keragaman sedang. 0,61-1 Dominansi tinggi, keragaman rendah.

Isolasi dan karakterisasi bakteri anaerob. Bakteri feses diisolasi menggunakan teknik serial dilusi pada pelarut $\mathrm{NaCl} 0,9 \%$. Sampel yang diperoleh dari hasil pengenceran berseri diambil sebanyak $0,1 \mathrm{~mL}$ dan diinokulasikan ke dalam cawan petri steril. Media yang digunakan yaitu peptone yeast glucose (PYG) agar untuk mengisolasi bakteri anaerob fakultatif dan obligat, kemudian dilakukan teknik pour plate. Inkubasi dilakukan dalam anaerobic jar selama 48 jam pada suhu $37^{\circ} \mathrm{C}$. Karakterisasi koloni dilakukan dengan cara mengamati karakter morfologi yang tampak. Karakter yang diamati diantaranya yaitu bentuk, konfigurasi, elevasi, ciri optik, tekstur, warna, tepi dan adanya zona bening. Pemurnian dilakukan menggunakan teknis four way streak plate hingga diperoleh kultur murni. Isolat murni dikultur pada media agar sebagai isolat stok dan disimpan pada coolroom dengan suhu $4^{\circ} \mathrm{C}$ untuk digunakan pada uji selanjutnya.

Isolasi DNA bakteri. Bakteri ditumbuhkan dalam media Luria Bertani (LB) broth sebanyak $3 \mathrm{~mL}$ selama 16 jam pada suhu $37^{\circ} \mathrm{C}$. Kultur bakteri dalam media LB disentrifus dengan kecepatan $10.000 \mathrm{rpm}$, suhu $25^{\circ} \mathrm{C}$ selama 5 menit. Pelet yang diperoleh ditambah buffer lysis (EDTA 0,5M pH 8, Tris-Cl $1 \mathrm{M} \mathrm{pH}$ $8, \mathrm{NaCl} 5 \mathrm{M}$, sodium dedocyl sulfate (SDS) $10 \%$, akuades dan proteinase- $\mathrm{K} 5 \mathrm{mg} / \mathrm{ml}$ ) sebanyak $1 \mathrm{~mL}$ dan diinkubasi pada suhu $37^{\circ} \mathrm{C}$ selama 1 jam. Selanjutnya tahapan isolasi DNA bakteri anaerob pada sampel feses mengikuti metode sebelumnya [21]. Ekstrak DNA yang didapatkan dideteksi dengan elektroforesis gel agarosa $0,8 \%$ dengan tegangan 100 volt selama 60 menit. Pita DNA yang terbentuk kemudian dibandingkan dengan marker $1 \mathrm{~kb}$.

Amplifikasi dengan PCR. DNA kromosomal diamplifikasi menggunakan metode Polymerase Chain Reaction (PCR). Primer yang digunakan yaitu Universal, Bacteroides, Clostridium, Bifidobacterium, Enterococcus, dan Lactobacillus (tabel 1) [22]. Ekstrak DNA dilarutkan dengan mix solution PCR. Campuran larutan tersebut kemudian dimasukkan dalam mesin PCR, hot start $95^{\circ} \mathrm{C}$ selama 3 menit, denaturasi pada suhu $95^{\circ} \mathrm{C}$ selama 30 detik, annealing pada $55^{\circ} \mathrm{C}$ selama 30 detik, ekstensi $72^{\circ} \mathrm{C} 5$ menit, dan post ekstensi. Program ini dilakukan sebanyak 31 siklus.. Amplikon dilihat menggunakan gel elektroforesis. Konsentrasi gel agarose yang 
digunakan yaitu $1,5 \%$ dan di running pada voltase 100 volt selama 45 menit. Marker yang digunakan adalah DNA ladder 100 bp. Gel yang berisi amplikon PCR divisualisasikan menggunakan gel doc.

Tabel 1. Primer amplifikasi DNA bakteri yang

\begin{tabular}{|c|c|}
\hline \multicolumn{2}{|c|}{ digunakan dalam penelitian ini [22] } \\
\hline Primer & Primer sequence (5'-3') \\
\hline V6-V8:_F & TACGGGAGGCAGCAG \\
\hline V6-V8:_R & ATTAACCGCGGCTGCTGG \\
\hline g-Bifid $F$ & CTCCTGGAAACGGGTGG \\
\hline g-Bifid R & GGTGTTCTTCCCGATATCTACA \\
\hline Ent.1017F & CCTTTGACCACTCTAGAG \\
\hline Ent.1263R & CTTAGCCTCGCGACT \\
\hline Lac1F & AGCAGTAGGGAATCTTCCA \\
\hline Lac2R & ATTYCACCGCTACACATG \\
\hline Bact_596F & TCAGTTGTGAAAGTTTGCG \\
\hline Bact_826R & GTRTATCGCMAACAGCGA \\
\hline Ccoc_F & AAATGACGGTACCTGACTAA \\
\hline Ccoc_R & CTTTGAGTTTYATTCTTGCGAA \\
\hline
\end{tabular}

Analisis statistik. Rancangan penelitian yang digunakan dalam penelitian ini menggunakan Rancangan Acak Lengkap (RAL). Analisis komposisi bakteri pada sampel menggunakan indeks Simpson. Analisis data melalui statistika deskriptif dengan One Way ANOVA menggunakan SPSS 16.0 pada signifikansi $\mathrm{p}<0,05$.

\section{HASIL DAN PEMBAHASAN}

Total koloni yang tumbuh pada media PCA sangat beragam pada masing - masing perlakuan. Perlakuan kontrol (C) memiliki nilai TPC sebesar $2,85 \times 10^{5} \mathrm{CFU} / \mathrm{mL}$, sedangkan kontrol yang diberi perlakuan protein CSN1S2 susu (CM) memiliki nilai paling kecil 0,46×10 $\mathrm{CFU} / \mathrm{mL}$ dan signifikan terhadap RAM $(\mathrm{p}<0,05)$. Kontrol yang diberi perlakuan protein CSN1S2 yogurt (CY) memiliki nilai $1,53 \times 10^{5}$ $\mathrm{CFU} / \mathrm{mL}$, sedangkan pada tikus RA memiliki nilai total bakteri $0,61 \times 10^{5} \mathrm{CFU} / \mathrm{mL}$ dan signifikan terhadap RAM ( $p<0,05)$. Tikus RA yang diberi perlakuan protein CSN1S2 susu (RAM) menunjukkan peningkatan yang signifikan dengan jumlah bakteri yang lebih besar dibanding perlakuan lainnya yaitu $8,00 \times 10^{5} \mathrm{CFU} / \mathrm{ml}$ serta signifikan terhadap perlakuan CM dan RA ( $\mathrm{p}<0,05)$, kemudian yang terakhir RA yang diberi perlakuan yogurt (RAY) juga terjadi peningkatan total koloni yaitu $3,23 \times 10^{5} \mathrm{CFU} / \mathrm{ml}$.

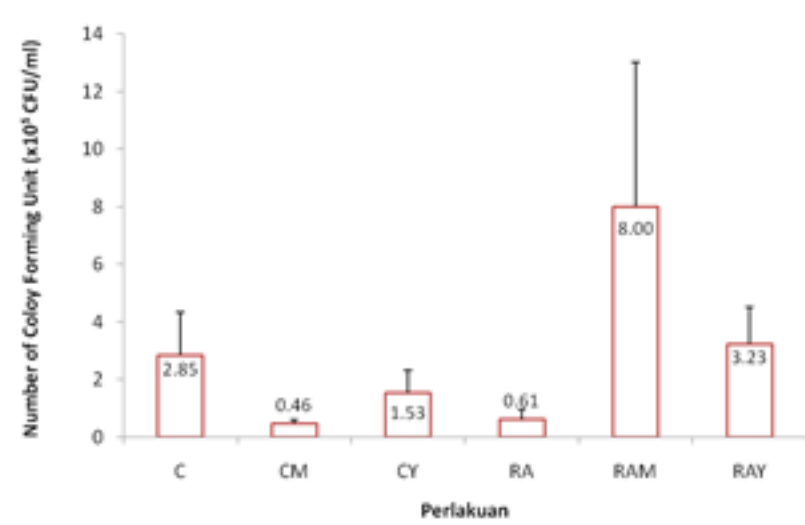

Gambar 1. Jumlah total koloni bakteri pada tiap perlakuan

Usus manusia memiliki beragam jenis mikroorganisme yang dapat membentuk sistem kekebalan pada tubuh manusia [23]. Berdasarkan hasil penelitian menunjukkan adanya perbedaan signifikan pada jumlah total koloni bakteri perlakuan RA dan kontrol yang telah diberi perlakuan protein CSN1S2 susu dan yogurt. Di sana terjadi penurunan total koloni bakteri pada perlakuan RA jika dibandingkan dengan perlakuan C. Nilai TPC yang berbeda pada setiap perlakuan disebabkan oleh perlakuan yang diberikan pada hewan model RA. Komposisi mikrobiota pada tikus RA berbeda dengan kontrol, dengan pengurangan atau penambahan jenis bakteri tertentu. Ada beberapa faktor yang dapat mengubah komposisi mikrobiota usus, termasuk genetik inang, diet, usia, tipe kelahiran, dan pemakaian antibiotik [24-27]. Perubahan penurunan komposisi mikrobiota pada model hewan RA menyebakan kondisi yang disebut dengan disbiosis yang dapat dianalisis melalui analisis feses [28]. Tikus yang diinduksi dengan CFA mempengaruhi komposisi mikrobiota usus pada model hewan RA. Hal ini terlihat pada model hewan RA, dimana terjadi perubahan yakni penurunan jumlah total koloni bakteri. Penelitian sebelumnya menyebutkan bahwa induksi CFA menyebabkan penurunan pada jenis bakteri Bacteroides dan terjadi peningkatan pada jenis Lactobacillaceae and Lachnospiraceae [29].

Senyawa CFA efektif dalam merangsang imunitas yang diperantarai sel dan mengarah pada potensiasi sel $\mathrm{T}$-helper yang mengarah pada produksi imunoglobulin dan sel T efektor tertentu [30]. Injeksi model hewan RA dengan CFA sebagai agen inflamasi dapat menginduksi imunitas adaptif yang merangsang sel T-helper untuk melepaskan IL-17 sehingga terjadi respon inflamasi yang menyebabkan kerusakan pada usus [18]. Studi dengan tikus gnotobiotik 
telah menunjukkan bahwa gangguan pada mikrobiota usus dapat menyebabkan produksi sitokin proinflamasi, interleukin-17, dan peningkatan kadar sel Th17. Sel Th17 kemudian bermigrasi ke jaringan limfoid perifer dan mengeluarkan IL-17, yang pada gilirannya, bertindak langsung pada sel B dan menginduksi diferensiasi sel $\mathrm{B}$ sistemik dan produksi antibodi, yang akhirnya dapat mengarah pada pengembangan penyakit autoimun melalui pengenalan pola molekul dari mikrobiota usus [1]. Protein CSN1S2 susu dan yogurt dapat menekan efek inflamasi secara tidak langsung melalui peningkatan IL-10 terhadap IL-17. Studi terbaru juga melaporkan bahwa IL-10 dapat menekan Th-17 sehingga menurunkan level IL-17 [31]. Hal ini ditunjukkan dari perubahan jumlah total koloni bakteri pada RA yang diberi perlakuan protein CSN1S2 susu dan yogurt, dimana terjadi peningkatan yang signifikan pada perlakuan RAM dibandingkan RAY (meningkat dibandingkan $\mathrm{CM}$ dan $\mathrm{CY}$ ), sehingga dapat dikatakan bahwa pemberian protein CSN1S2 susu dan yogurt kambing ethawah dapat mengembalikan koloni bakteri yang berkurang akibat inflamasi yang terjadi pada model hewan RA. Meningkatnya total koloni bakteri pada perlakuan RAM dan RAY menunjukkan adanya pengaruh dari pemberian protein CSN1S2 susu dan yogurt kambing ethawah yang mampu mengembalikan koloni komensal bakteri di usus.

Susu dianggap berperan penting dalam diet yang seimbang karena kaya akan protein berkualitas tinggi, serta komponen bioaktif yang mempromosikan kesehatan [32]. Meningkatnya jumlah total koloni pada perlakuan RA yang diberi susu lebih tinggi dibandingkan dengan RA yang diberi yogurt dapat disebabkan oleh peptida bioaktif yang berasal dari protein susu. Susu kambing dapat membantu dalam mempertahankan homeostasis inflamasi dengan merangsang produksi beberapa sitokin dengan berbagai efek, seperti TNF- $\alpha$ (sitokin proinflamasi), IL-6 (reaktan fase akut dan faktor pertumbuhan untuk sel B), dan IL -10 (sitokin anti inflamasi) [33].

Tabel 2. Karakter morfologi bakteri anaerob

\begin{tabular}{|c|c|c|c|c|c|c|c|}
\hline ISOLAT & Bentuk & Konfigurasi & Elevasi & Ciri Optik & Tektstur & Warna & Tepi \\
\hline 2 & $\begin{array}{l}\text { tidak } \\
\text { teratur }\end{array}$ & beralun & datar & Opalesens & kasar & putih & bergerigi \\
\hline 4 & bulat & menyeluruh & datar & $\begin{array}{l}\text { miring } \\
\text { vertikal }\end{array}$ & halus & putih & halus \\
\hline 6 & bulat & menyeluruh & datar & pudar & halus & putih & halus \\
\hline 7 & bulat & menyeluruh & datar & $\begin{array}{l}\text { miring } \\
\text { horizontal }\end{array}$ & halus & putih & halus \\
\hline 11 & $\begin{array}{l}\text { tidak } \\
\text { teratur }\end{array}$ & berserabut & datar & seperti debu & kasar & $\begin{array}{l}\text { putih } \\
\text { bening }\end{array}$ & serabut \\
\hline 13 & Bulat & Menyeluruh & Datar & Kecil & Halus & Putih & Halus \\
\hline 17 & bulat & menyeluruh & datar & $\begin{array}{l}\text { mengkilat, } \\
\text { opalesens }\end{array}$ & halus & $\begin{array}{l}\text { putih } \\
\text { menyala }\end{array}$ & halus \\
\hline 20 & bulat & menyeluruh & datar & $\begin{array}{l}\text { miring } \\
\text { horizontal, } \\
\text { pudar,tipis }\end{array}$ & halus & $\begin{array}{l}\text { putih } \\
\text { tipis }\end{array}$ & halus \\
\hline 21 & bulat & menyeluruh & datar & $\begin{array}{l}\text { mengkilat, } \\
\text { iridesens }\end{array}$ & kasar & $\begin{array}{l}\text { putih } \\
\text { menyala }\end{array}$ & beralun \\
\hline 26 & bulat & menyeluruh & datar & pudar & halus & $\begin{array}{l}\text { putih } \\
\text { tipis }\end{array}$ & halus \\
\hline
\end{tabular}

Protein kasein seperti CSN1S2 dari susu kambing Ethawah memiliki fungsi biologis sebagai imunomodulator, namun memiliki respon yang berbeda dari protein yogurt CSN1S2 [18]. Protein CSN1S2 pada yogurt kambing Ethawah memiliki mekanisme berbeda untuk mengontrol fungsi fisiologis yang mungkin gagal untuk mengontrol ketidakseimbangan flora di usus [34], sehingga tampak perubahan yang tidak terlalu signifikan pada RA yang diberi perlakuan yogurt. 
Berdasarkan hasil isolasi bakteri anaerobik dari sampel feses berbagai perlakuan selama 48 jam di dalam anaerobic jar diperoleh isolat dengan karakteristik morfologi yang berbeda beda. Karakterisasi secara makroskopik meliputi pengamatan morfologi koloni bakteri dengan mengamati bentuk, konfigurasi, elevasi, ciri optik, tekstur, warna, dan tepi yang tumbuh pada media peptone yeast glucose (PYG). Hasil pengamatan makroskopik koloni bakteri yang berhasil diisolasi dapat dilihat pada Tabel 2 .

Berdasarkan hasil karakteristik morfologi yang telah dilakukan, kemudian digunakan untuk menentukan indeks diversitas. Indeks diversitas yang digunakan adalah indeks Simpson yang berfungsi untuk mengetahui tingkat dominansi pada masing - masing perlakuan. Hasil menunjukkan nilai indeks Simpson yang beragam baik C, CM, CY, RA, RAM, dan RAY. Secara berturut - turut nilai indeks Simpson yaitu 0,98, 0,97, 0,60, 0,89, 0,93, 0,83. Perlakuan C memiliki nilai indeks Simpson paling tinggi dan CY memiliki nilai indeks Simpson paling rendah. Tingginya nilai indeks Simpson menunjukkan adanya dominansi bakteri pada perlakuan C, CM, RA, RAM, RAY, dan dominansi sedang pada perlakuan $\mathrm{CY}$. Isolat yang mendominasi pada setiap perlakuan yaitu isolat 13 dan Isolat 4, dimana isolat tersebut terdapat pada setiap perlakuan, sehingga menyebabkan adanya kodominan pada perlakuan C, CM, RA, RAM, dan RAY (Gambar 2).

Ketidakseimbangan flora di usus dapat diketahui dengan analisis indeks keanekaragaman. Pengamatan koloni bakteri secara makroskopis pada media PYG ditemukan sebanyak 26 isolat yang memiliki karakter morfologi yang berbeda - beda. Data morfologi yang didapatkan selanjutnya dipakai untuk mengetahui keanekaragaman mikroba dengan indeks Simpson. Nilai indeks Simpson menunjukkan adanya dominansi yang terjadi pada setiap perlakuan. Dapat dilihat pada Gambar 2 perlakuan kontrol memiliki dominansi paling tinggi dibandingkan perlakuan lain, sehingga dapat diketahui bahwa keanekaragaman bakteri pada kelompok RA lebih beragam dibandingkan perlakuan lain.

Komposisi mikrobiota usus ditentukan dan dipengaruhi oleh sejumlah faktor endogen dan eksogen, seperti asal geografis, usia, genetika, pola makan, dan penggunaan prebiotik dan antibiotik [35]. Pola makan sangat mempengaruhi kesehatan manusia, sebagian besar dengan memodulasi komposisi mikrobiota yang ada di usus [36]. Susu dan yogurt dalam hal ini merupakan salah satu nutrisi yang mempengaruhi komposisi mikrobiota pada model hewan kontrol dan RA.

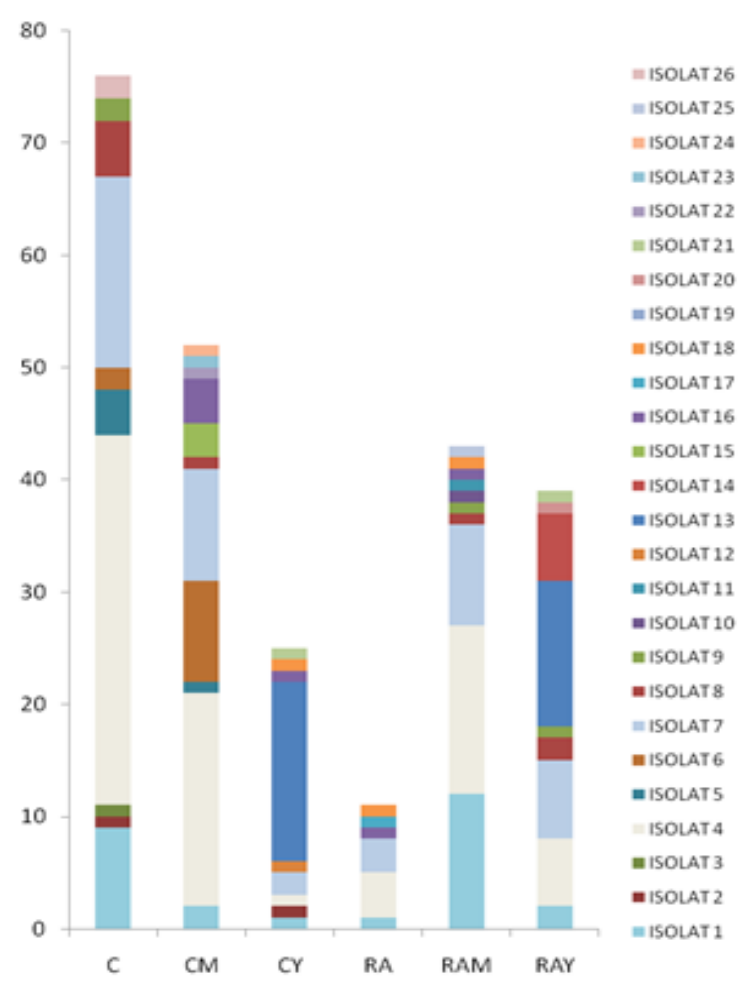

Gambar 2. Diversitas komposisi bakteri anaerob pada setiap perlakuan

Isolat terpilih yang telah dikarakterisasi sebelumnya, selanjutnya dilakukan identifikasi famili menggunakan teknik molekuler gen $16 \mathrm{~S}$ rRNA. Isolat yang dipilih merupakan perwakilan dari masing - masing kelompok perlakuan. Isolasi total genom dilakukan untuk mendapatkan ekstrak DNA. Hasil isolasi DNA whole genom bakteri yang telah didapatkan kemudian digunakan untuk amplifikasi gen target dengan primer spesifik yang telah ditentukan (Tabel 1). Produk PCR yang dihasilkan selanjutnya dielektroforesis untuk mengetahui ukuran hasil amplifikasi dan famili dari setiap isolat terpilih. Hasil amplifikasi menggunakan primer universal menunjukkan bahwa semua isolat terpilih teramplifikasi. Hasil amplifikasi pada kelompok bakteri Lactobacillus menunjukkan hal yang sama, dimana semua isolat terpilih teramplifikasi. Namun semua isolat tidak teramplifikasi menggunakan primer lain seperti Bifidobacterium, Bacteroides, Clostridium, dan Enterococcus, yang dapat dikatakan bahwa semua isolat tidak termasuk kedalam famili bakteri yang telah disebutkan sebelumnya. Dari hasil ini ketahui bahwa sampel feses tersebut didominasi oleh bakteri Lactobacillus. 
Studi yang menggunakan amplifikasi PCR gen 16S RNA dengan enam primer yang berbeda menunjukkan bahwa sepuluh isolat terpilih diatas, telah teramplifikasi dengan primer Lactobacillus. Hal ini menunjukkan bahwa 10 isolat yang terpilih dari perwakilan masing - masing perlakuan, termasuk ke dalam kelompok bakteri Lactobacillus baik yang ditemukan ada sampel kontrol dan RA. Kelompok Bakteri Bifidobacterium, Clostridium, dan Bacteroides mengalami penurunan pada penderita RA [37]. Hal ini dapat dilihat pada hasil PCR dimana tidak teramplifikasi gen dari kelompok bakteri diatas. Suplementasi dengan probiotik telah terbukti mengurangi aktivitas RA pada arthritis yang diinduksi kolagen dan mengurangi manifestasi penyakit. Selain itu, sitokin inflamasi (interleukin [IL]-1b, IL-2, IL-6, IL-12, IL-17, interferon [IFN]- $\gamma$, tumor necrosis factor $[\mathrm{TNF}]-\alpha)$ menurun [38]. Strain probiotik Bifidobacterium, Lactobacillus, dan Streptococcus menekan ekspresi sitokin pro-

\section{Universal}

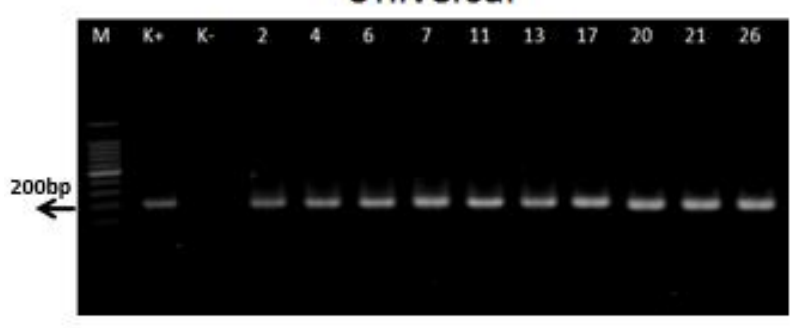

Bacteroides

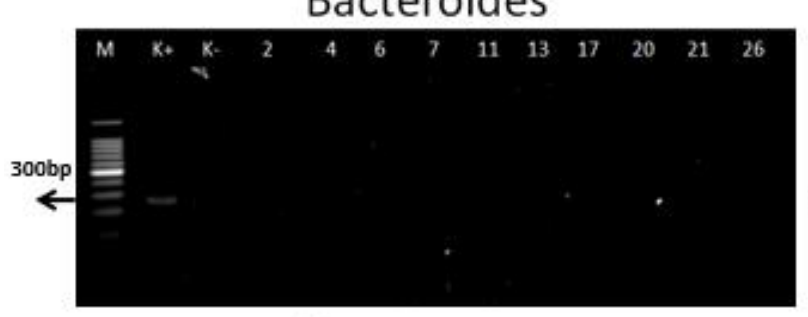

Enterococcus

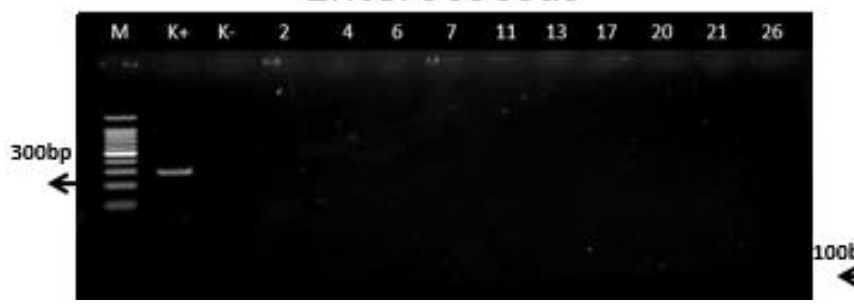

Gambar 3. Hasil amplifikasi gen $16 \mathrm{~S}$ sRNA dengan enam primer target

Saluran gastrointestinal (GI) membentuk ekosistem kompleks yang berfungsi bersamaan dengan mikrobiota sebagai penghalang struktural dan fungsional yang melindungi tuan rumah dari serangan oleh mikroorganisme enterovirulen berbahaya yang tidak diinginkan inflamasi IL-6 dan IL-7, dan menstimulasi ekspresi protein $\mathrm{TJ}$, yang mengarah pada peningkatan stabilitas penghalang. Bakteri $L$. rhamnosus GG berinteraksi dengan sel-sel usus dan mempertahankan integritas gut blood barrier (GBB) [39]. Bakteri Lactobacillus casei adalah di antara sedikit lactic acid bacteria (LAB) yang dikenal sebagai probiotik dan telah sering dilaporkan memiliki efek pengaturan kekebalan pada penelitian model hewan [40]. Lactobacillus casei terbukti secara signifikan mengurangi ekspresi sitokin proinflamasi, yaitu aktivitas IL-6 dan TNF- $\alpha$, dan COX-2, mengurangi manifestasi RA [41]. Sebaliknya, Lactobacillus bifidus menunjukkan kemungkinan kemampuan untuk mempromosikan pembengkakan sendi pada tikus bebas kuman, dengan aktivasi TLR2/TLR4 [42]. Penelitian ini mununjukkan jika spesies Lactobacillus yang ditemukan pada kelompok RA mungkin didominasi oleh bakteri Lactobacillus bifidus.
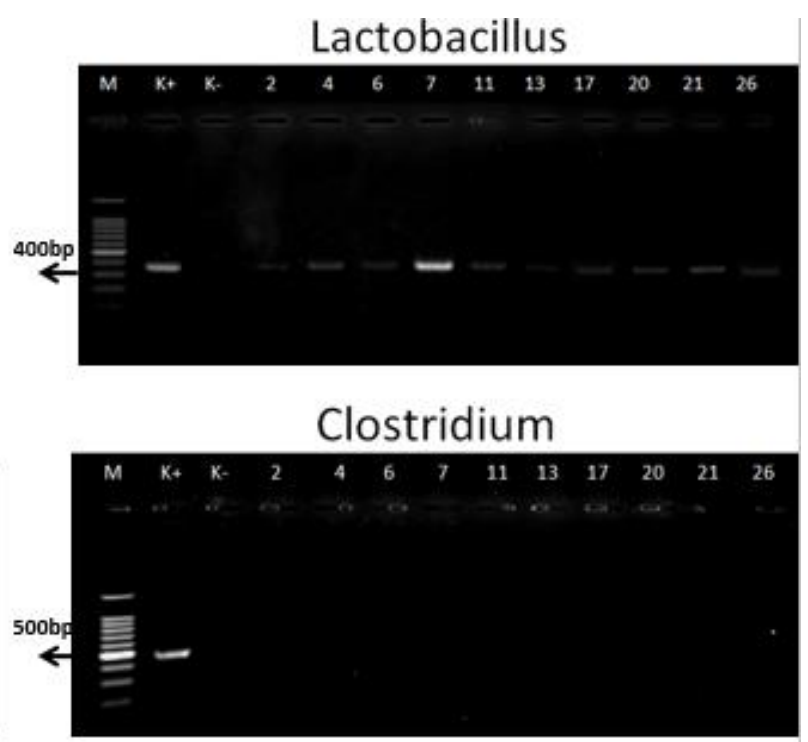

Bifidobacterium

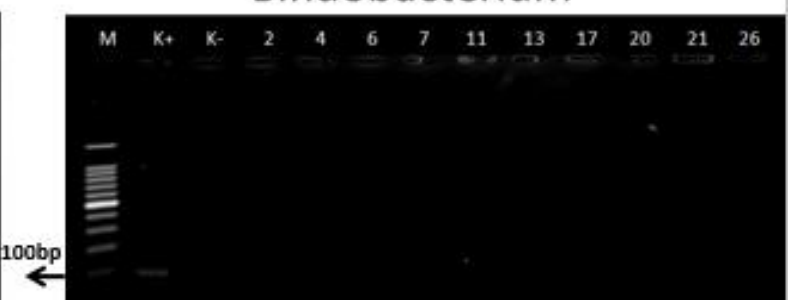

[43]. Mikrobiota secara efisien dapat membatasi infeksi usus oleh bakteri patogen. Selama infeksi patogen, mikrobiota memiliki beberapa fungsi utama yaitu menghambat pertumbuhan patogen, melindungi pertahanan imun bawaan dan adaptif inang, serta 
membantu menghilangkan patogen dari lumen usus pada akhir infeksi [44]. Spesies bakteri tertentu mampu menghambat pertumbuhan bakteri jenis lain, termasuk patogen dimana salah satunya dengan melepaskan metabolit penghambatan (asetat dan butirat) dan bakteriosin [45]. Bakteri Gram positif, terutama bakteri asam laktat (lactobacilli, lactococci, dan pediococci) dapat menghasilkan peptida antimikroba dan protein dalam ribosom, seperti lactacin B dari Lactobacillus acidophilus. Strain Lactobacillus menampilkan aktivitas antibakteri dapat menurunkan ekspresi faktor virulensi patogen enterovirulent [46-48]. Hal ini membuktikan jika bakteri dari strain Lactobacillus ternyata mempunyai efek positif untuk menghambat pertumbuhan kelompok bakteri Gram negatif seperti Clostridium dan Enterococcus.

\section{KESIMPULAN}

Pemberian protein CSN1S2 susu dan yogurt peranakan ethawah memberikan pengaruh terhadap jumlah bakteri pada model hewan kontrol dan RA. Komposisi mikrobiota pada usus tikus RA yang diinduksi dengan CFA setelah diberikan protein CSN1S2 dari susu dan yogurt didominasi oleh kelompok bakteri Lactobacillus baik pada kontrol maupun RA. Bakteri Lactobacillus dapat berperan dalam mempengaruhi perkembangan penyakit RA, serta mampu menghambat bakteri pathogen dari golongan Clostridium dan Enterococcus.

\section{UCAPAN TERIMA KASIH}

Penulis mengucapkan terimakasih atas dukungan pendanaan dari grant DPP/SPP, Fakultas Matematika dan Ilmu Pengetahuan Alam, Universitas Brawijaya no. 1/UN10.F09.01/PG/2019.

\section{DAFTAR PUSTAKA}

[1] Baas H, Romero FG, Montiel JM, Pizano ZA, Garcia MM, Ramírez DN (2017) Intestinal dysbiosis and rheumatoid arthritis: a link between gut microbiota and the pathogenesis of rheumatoid arthritis. Journal Immunol 4835189. doi: 10.1155/2017/4835189.

[2] Halpern MT, Cifaldi MA, Kvien TK (2009) Impact of adalimumab on work participation in rheumatoid arthritis: comparison of an open-label extension study and a registrybased control group.
Ann Rheum Dis 68: 930 - 937. doi:10.1136/ard.2008.092734.

[3] RISKESDAS (2018) Hasil Utama Riskesdas. 2018. www.depkes.go.id. Accessed: April 2020.

[4] Wu HJ, Ivanov II, Darce J (2010) Gutresiding segmented filamentous bacteria drive autoimmune arthritis via T helper 17 cells. Immunity 32(6): 815-827. doi:10.1016/j.immuni.2010.06.001.

[5] Asquith M, Elewaut D, Lin P, Rosenbaum, JT (2014) The role of the gut and microbes in the pathogenesis of spondyloarthritis. Best Pract. Res. Clin. Rheumatol 28: 687-702. doi: 10.1016/j.berh.2014.10.018.

[6] Luckey JD, Gomez A, Murray J, White B, Taneja V (2013) Bugs \& us: the role of the gut in autoimmunity. The Indian Journal of Medical Research 138 (5): 732- 743.

[7] Inohara I, Chamaillard M, McDonald C (2005) NOD-LRR protein: role in hostmicrobial interactions and inflammatory disease. Annual Review of Biochemistry 74: $355 \quad-\quad 383 . \quad$ DOI: 10.1146/annurev.biochem.74.082803.133 34.

[8] Round JL, Mazmanian SK (2010) Inducible Foxp3+ regulatory T-cell development by a commensal bacterium of the intestinal microbiota. Proc. Natl. Acad. Sci. U.S.A 107: 12204-12209. doi: 10 . $1073 /$ pnas.0909122107//DCSupplemental.

[9] Scher JU, Sczesnak A, Longman RS, Segata N, Ubeda C, Bielski C, Rostron T, Cerundolo V, Pamer EG, Abramson SB, Huttenhower C, Littman DR (2013) Expansion of intestinal Prevotella copri correlates with enhanced susceptibility to arthritis. eLife 2: e01202. doi:10.7554/eLife.01202.

[10] Zhang X, Zhang D, Jia H (2015) The oral and gut microbiomes are perturbed in rheumatoid arthritis and partly normalized after treatment. Nat. Med 21: 895-905. DOI: 10.1038/nm.3914.

[11] Pickard JM, Zeng MY, Caruso R., Núñez G (2017) Gut microbiota: Role in pathogen colonization, immune responses, and inflammatory disease. Immunol Rev 279: (1):70-89. doi:10.1111/imr.12567.

[12] Wang Z, Jiang S, Ma C, Huo D, Peng Q, Shao Y, Zhang J (2018) Evaluation of the nutrition and function of cow and goat 
milk based on intestinal microbiota by metagenomic analysis. Food \& Function 9(4): 2320-2327. doi: $10.1039 / \mathrm{c} 7$ fo01780d.

[13] Rozila I, Ezni S, Lani MN, Sharina MD, Siti HM, Asma H, Sharida MD (2012) Antibacterial activity of lactic acid bacteria isolated from goats' milk. International Annual Symposium on Sustainability Science and Management: 09-11 Juli 2012; Terengganu, Malaysia.

[14] Mukhopadhya A, Noronha N, Bahar B, Ryan MT, Murray BA, Kelly PM (2014) Anti-inflammatory effects of a casein hydrolysate and its peptide enriched fractions on TNF $\alpha \alpha$-challenged Caco-2 cells and LPS-challenged porcine colonic explants. Food Sci Nutr 2(6): 712-23. doi: 10.1002/fsn3.153.

[15] Tripsilla LF, Suharjono S, Antonius C, Fatchiyah F (2016) The Comparing of Antimicrobial Activity of CSN1S2 Protein of Fresh Milk and Yogurt Goat Breed Ethawah Inhibited the Pathogenic Bacteria. Mater Sociomed 28(4): 244-248. DOI: $10.5455 / \mathrm{msm} .2016 .28 .244-248$

[16] Budiarti IK, Padaga M, Fatchiyah F (2013) Nutritional composition and protein profile of goat yogurt PE with double culture between Streptococcus thermophilus and Lactobacillus species. Cukurova Medical Journal, 38:681-686.

[17] Fatchiyah F, Setiawan B, Suharjono S, Noor Z (2015) The anti-osteoporosis effects of CSN1S2 protein of goat milk and yoghurt on a complete Freund's adjuvant-induced rheumatoid arthritis model in rats. Biomarkers and Genomic Medicine 7(4):139-146. https://doi.org/10.1016/j.bgm.2015.10.00 1

[18] Rohmah RN, Widjajanto E, Fatchiyah F (2015) Protective effect of CSN1S2 protein of goat milk on ileum microstructure and inflammation in ratCFA induced rheumatoid arthritis. Asian Pacific Journal of Tropical Disease 5(7): 564-568. doi: 10.1016/S22221808(15)60837-4.

[19] Lee JY, Mannaa M, Kim Y, Seo YS (2019) Comparative analysis of fecal microbiota composition between rheumatoid arthritis and osteoarthritis patients. Genes 10(748): 1-14.

[20] Bibi F, Ali Z (2013) Measurement of diversity indices of Avian communities at Taunsa barrage wildlife sanctuary,
Pakistan. The Journal of Animal Planet \& Sciences 23(2): 469-474.

[21] Fatchiyah, Arumingtyas EL, Widyarti S, Rahayu S (2011) Biologi Molekuler Prinsip Dasar Analisis. Erlangga. Jakarta.

[22] Yusuf F, Ilyas S, Damanik HAR, Fatchiyah (2016) Microbiota composition, HSP70 and Caspase-3 expression as marker for colorectal cancer patients in Aceh, Indonesia. The Indonesian Journal of Internal Medicine 48(4): 289-299. PMID: 28143990.

[23] Sandhya P, Danda D, Sharma D, Scaria V (2016) Does the buck stop with the bugs?: an overview of microbial dysbiosis in rheumatoid arthritis. International Journal of Rheumatic Diseases 19: 8-20.

[24] Odamaki T, Kato K, Sugahara H, Hashikura N, Takahashi S, Xiao JZ, Abe F, Osawa R (2016) Age-related changes in gut microbiota composition from newborn to centenarian: a crosssectional study. BMC Microbiology 16(1): 90. doi: 10.1186/s12866-016-0708-5.

[25] Jandhyala SM, Talukdar R., Subramanyam C, Vuyyuru H, Sasikala M, Reddy DN (2015) Role of the normal gut microbiota. World Journal of Gastroenterology 21(29):8787. doi: 10.3748/wjg.v21.i29.8787.

[26] Nagpal R, Tsuji H, Takahashi T, Nomoto K, Kawashima K, Nagata S, Yamashiro Y (2017) Ontogenesis of the gut microbiota composition in healthy, full-term, vaginally born and breastfed infants over the first 3 years of life: a quantitative bird's-eye view. Frontiers in Microbiology 8:1388. doi:10.3389/fmicb.2017.01388.

[27] Goodrich JK, Waters JL, Poole AC, Sutter JL, Koren O, Blekhman R, Beaumont M, Van Treuren W, Knight R, Bell JT, Spector TD, Clark AG, Ley RE (2014) Human genetics shape the gut microbiome. Cell 159(4):789-799. DOI 10.1016/j.cell.2014.09.053.

[28] Bäumler, A.J. \& Sperandio, V. Interactions between the microbiota and pathogenic bacteria in the gut. Nature. 2016; 535(7610):85-93. doi: 10.1038/nature18849.

[29] Liu X, Zeng B, Zhang J, Li W, Mou F, Wang $\mathrm{H}$ (2016) Role of the gut microbiome in modulating arthritis progression in mice. Sci Rep 6: 30594. doi:10.1038/srep30594. 
[30] Armentero MT, Levandis G, Nappi G, Bazzini E, Blandini F (2006) Peripheral inflammation and neuroprotection: systemic pretreatment with complete Freund's adjuvant reduces 6hydroxydopamine toxicity in a rodent model of Parkinson's disease. Neurobiol 24(3): 492-505. doi:10.1016/j.nbd.2006.08.016.

[31] Gu Y, Yang J, Ouyang X (2008) Interleukin 10 suppresses Th17 cytokines secreted by macrophages and T cells. Eur J Immunol 38(7): 1807-1813. doi:10.1002/eji.200838331.

[32] Pfeuffer M, Schrezenmeir, J (2007) Milk and the metabolic syndrome. Obes. Rev 8: 109-118.

[33] Amati L, Marzulli G, Martulli M, Tafaro A, Jirillo F, Pugliese V, Martemucci G, D'Alessandro AG, Jirillo E (2010) Donkey and Goat Milk Intake and Modulation of the Human Aged Immune Response. Current Pharmaceutical Design 16: 864-869. doi: 10.2174/138161210790883651.

[34] Serino M, Luche E, Chabo C, Amar J, Burcelin R. Intestinal microflora and metabolic diseases. Diabetes Metab 35(4): 262-72.

doi: 10.1016/j.diabet.2009.03.003.

[35] Strzepa A, Majewska-Szczepanik M, Lobo FM (2017) Broad spectrum antibiotic enrofloxacin modulates contact sensitivity through gut microbiota in a murine model. J Allergy Clin Immunol 140(1): 121-133. doi: 10.1016/j.jaci.2016.11.052.

[36] Wu GD, Chen J, Hoffmann C (2011) Linking long-term dietary patterns with gut microbial enterotypes. Science 334 (6052):105-108. doi:10.1126/science.1208344.

[37] Seksik P, Rigottier-Gois L, Gramet G (2003) Alterations of the dominant faecal bacterial groups in patients with Crohn's disease of the colon. Gut 52(2): 237-242. doi:10.1136/gut.52.2.237.

[38] Amdekar S, Singh V, Singh R, Sharma P, Keshav P, Kumar A (2011) Lactobacillus casei reduces the inflammatory joint damage associated with collagen-induced arthritis (CIA) by reducing the proinflammatory cytokines. J Clin Immunol 31: 141-54. doi: 10.1007/s10875-0109457-7.

[39] Bajaj BK, Claes IJ, Lebeer S (2015) Functional mechanisms of probiotics. J.
Microbiol. Biotechnol. Food Sci 4: 321327. doi: 10.15414/jmbfs. 2015.4.4.321327.

[40] Anal AK, Singh H (2007) Recent advances in microencapsulation of probiotics for industrial applications and targeted delivery. Trends Food Sci Technol 18: 242-5.

[41] Alipour B, Homayouni-Rad A, VaghefMehrabany E, Sharif SK, VaghefMehraany L, Asghari-Jafarabadi M (2020) Effects of Lactobacillus casei supplementation on disease activity and inflammatory cytokines in rheumatoid arthritis patients: a randomized doubleblind clinical trial. Int $\mathrm{J}$ Rheum Dis 17:519-27. doi: 10.1111/1756185X.12333.

[42] Bdollahi-Roodsaz S, Joosten LA, Koenders MI, Devesa I, Roelofs MF, Radstake TR (2008) Stimulation of TLR2 and TLR4 differentially skews the balance of $\mathrm{T}$ cells in a mouse model of arthritis. $\mathrm{J}$ Clin Invest 118: 205-16. doi: 10.1172/JCI32639.

[43] Lievin-Le MV, Servin AL (2006) The front line of enteric host defense against unwelcome intrusion of harmful microorganisms: mucins, antimicrobial peptides, and microbiota. Clin. Microbiol. Rev 19: 315-337. doi:10.1128/CMR.19.2.315-337.2006.

[44] Sekirov I, Russell SL, Antunes LC, Finlay BB (2010) Gut microbiota in health and disease. Physiol 90: 859-904. doi: 10.1152/physrev.00045.2009.

[45] Stecher B, Hardt WD (2008) The role of microbiota in infectious disease. Trends Microbiol. 16: 107-114. doi: 10.1152/physrev.00045.2009.

[46] Cotter PD, Ross RP, Hill C (2013) Bacteriocins a viable alternative to antibiotics? Nat. Rev. Microbiol 11:95105. doi: 10.1038/nrmicro2937.

[47] Dobson A, Cotter PD, Ross RP, Hill C (2012) Bacteriocin production: a probiotic trait? Appl. Environ. Microbiol 78:1-6. doi: 10.1128/AEM.05576-11.

[48] O'Shea EF, Cotter PD, Stanton C, Ross RP, Hill C (2012) Production of bioactive substances by intestinal bacteria as a basis for explaining probiotic mechanisms: bacteriocins and conjugated linoleic acid. Int. J. Food Microbiol 152: 189-205. 